\title{
TRAJETÓRIA E MEMÓRIAS NO ENSINO DA DANÇA: \\ CORRENTES PEDAGÓGICAS NO PROCESSO DE FORMAÇÃO
}

\author{
Ana Paula Darolt.paulad_ana@hotmail.com' \\ Giovana Bianca Darolt Hillesheim. giovana.bianca@ifsc.edu.br ${ }^{2}$
}

"Que nome dar a este lado de dentro do fora, ao afeto de si por si? Respondo: Memória".

(Deleuze, 1991, p. 104, apud ROSA, 2016 P. 12)

\section{O DESPERTAR PARA A DANÇA - CONTEXTO E INFLUÊNCIAS}

A dança esteve mais presente na minha vida de forma não formal, ao participar de pequenos grupos infantis que, em sua maioria, não se atinham a técnicas de modalidades específicas. No entanto, na educação formal, o universo das artes sempre foi algo bem próximo. Como filha e irmã de professoras, o ambiente escolar me era muito confortável e, consequentemente, me envolver com o que acontecia na escola de maneira artística, algo bem comum.

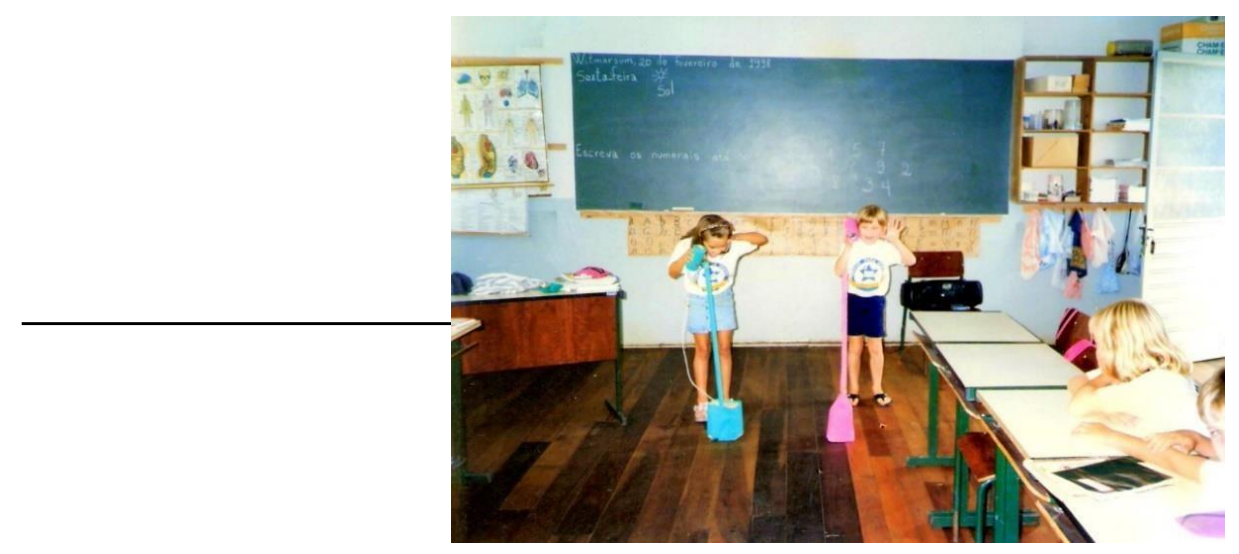

Figura 1: $1^{\circ}$ ano, 1997

Fonte: Arquivo pessoal

\footnotetext{
${ }^{1}$ Ana Paula Darolt é professora da Rede Estadual de Ensino de Santa Catarina; especialista em Arte Educação e graduanda em Dança pela FURB

${ }^{2}$ Giovana Bianca D. Hillesheim é professora do Instituto Federal de Santa Catarina; doutora em Artes Visuais pela UDESC com linha de pesquisa no ensino de Arte e formação de professores.
} 
Minha irmã mais velha e eu sempre tivemos personalidades e gostos parecidos. $\mathrm{O}$ amor pela arte talvez seja o mais significativo. Hoje, vendo que seguimos caminhos profissionais parecidos, percebo que ela sempre foi uma forte referência, até mesmo pelas pequenas coisas que me marcaram, como os quadros nas paredes com cenas do ballet, as roupas num estilo particular e propícias para dança, e outros detalhes que remetiam às Artes Cênicas e Visuais. Nela e no que a rodeava.

A "Jô" (Giovana Bianca D. Hillesheim) saiu de casa bastante jovem, para vivenciar a dança no Estado do Paraná. Quando voltou e, ainda durante minha infância, iniciou sua carreira acadêmica com um curso de Licenciatura em Artes Visuais. Foi então minha primeira professora na área. Mas antes mesmo de têla como professora na educação formal, eu já era uma de suas alunas nos grupos de dança infantil que liderava ${ }^{3}$. Como morávamos em uma cidade pequena, não havia muitas pessoas com conhecimento específico em dança, talento e disposição para estarem à frente de atividades assim. Também não havia tanto interesse e procura pelo ensino da dança ou qualquer outra área de arte, fora do contexto escolar. Sua iniciação como professora de dança era muito mais um hobby e amor, do que uma profissão. Qualquer espaço e tempo vago servia para realizarmos nossos ensaios. Um dia com 3 crianças no elenco, no outro com 10 , no outro com $15 \ldots$ Cada qual com as mais diversas habilidades/dificuldades de movimento.

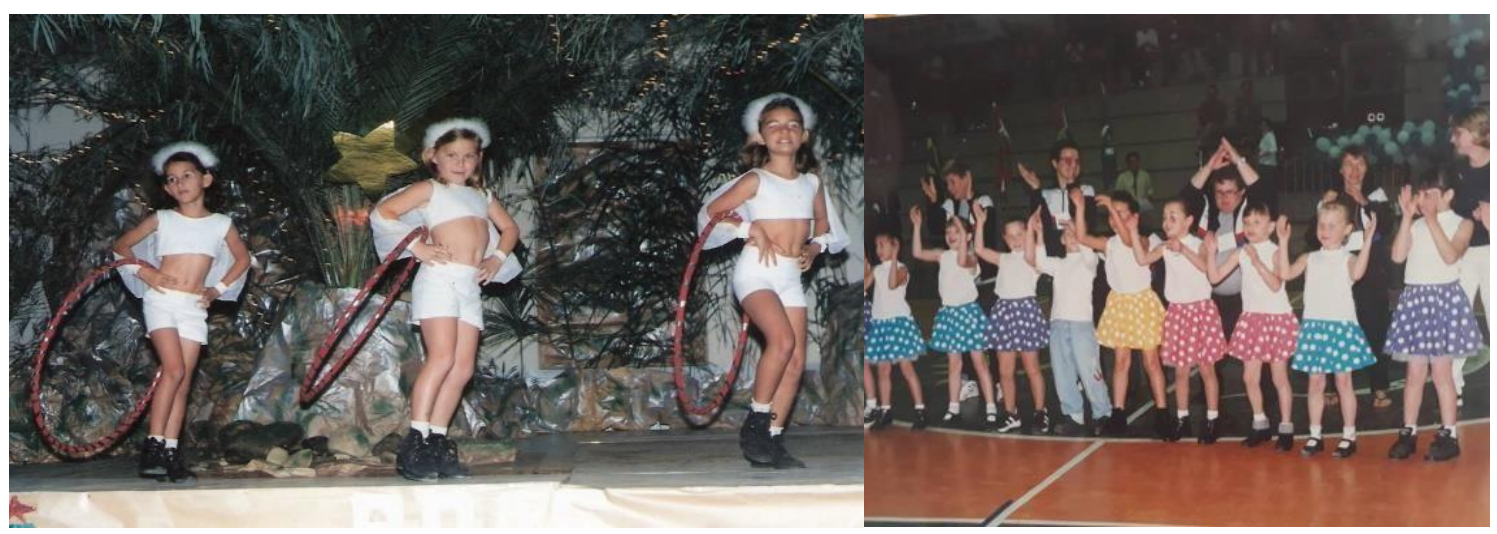

Figuras 2 e 3: Grupos e coreografias coordenadas pela professora Giovana (anos 90) Fonte: Arquivo pessoal.

${ }^{3}$ Grupos que variavam na formação, montados para apresentações específicas 

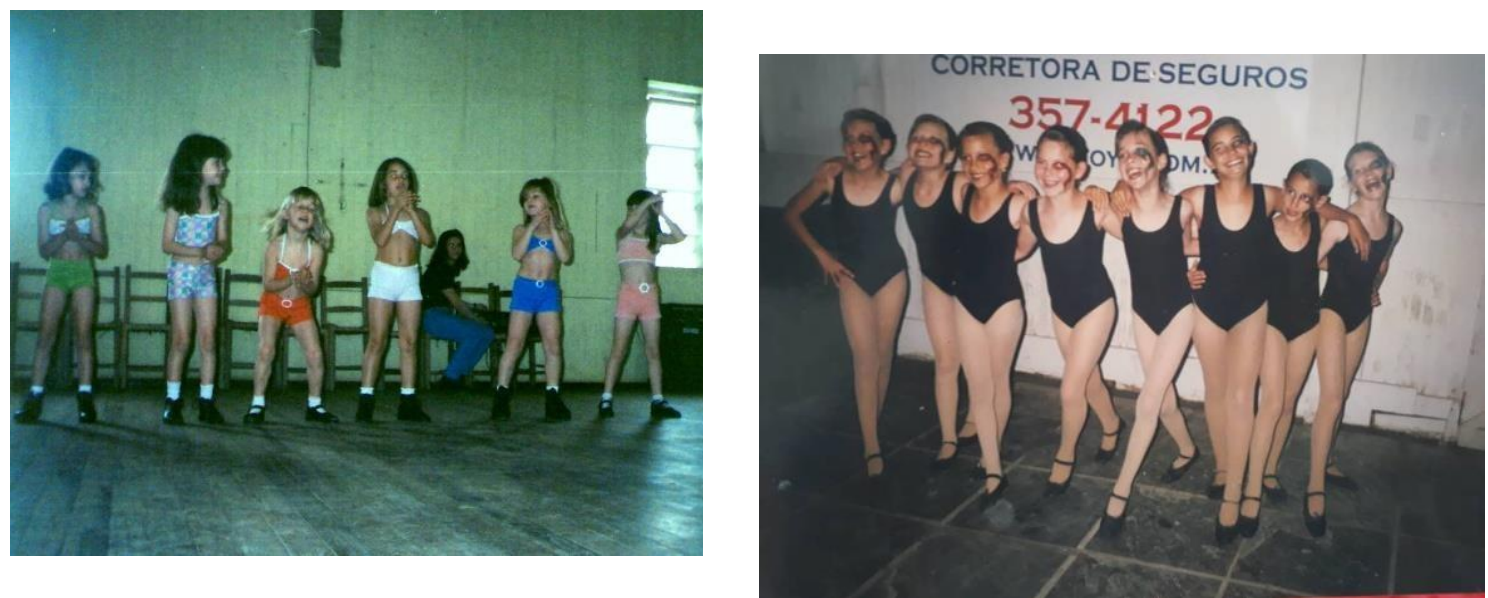

Figura 4 e 5: Grupos e coreografias coordenadas pela professora Giovana (anos 90) Fonte: Arquivo pessoal.

Éramos um grupo de meninas que ficaram encantadas com esse mundo que nos foi apresentado por ela. Estávamos sempre presentes nos eventos da cidade e, apesar de não me recordar muito dos processos e das aulas em si, me lembro que suas composições coreográficas sempre tinham o poder de surpreender e emocionar. Ela preocupava-se muito mais com o conjunto da obra do que com a execução de cada passo específico. Trazia sempre novidades, nas propostas. Escolha de músicas, figurinos, maquiagens e elementos cênicos que, por mais simples que fossem, faziam a diferença. Para nós, um pedaço de tecido, uma fita ou um bambolê era algo que transformava a dança e nos enchia de motivação.
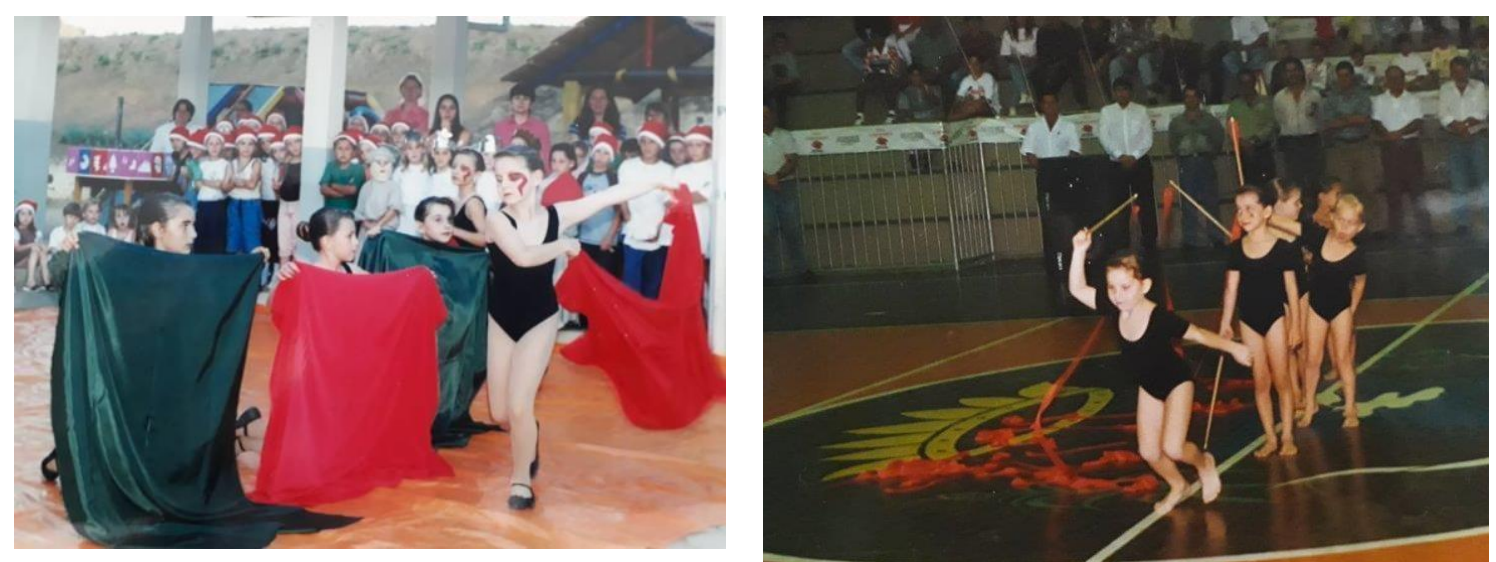

Figuras: 6 e 7: Elementos cênicos usados em algumas das coreografia Fonte: Arquivo pessoal

Revista "O Teatro Transcende" Departamento de Artes - CCEAL da FURB - ISSN 2236-6644 - Blumenau, Vol. 23, No 1, p. 92 - 110, 2018 - Edição Especial dos 45 Anos de Artes na FURB. 

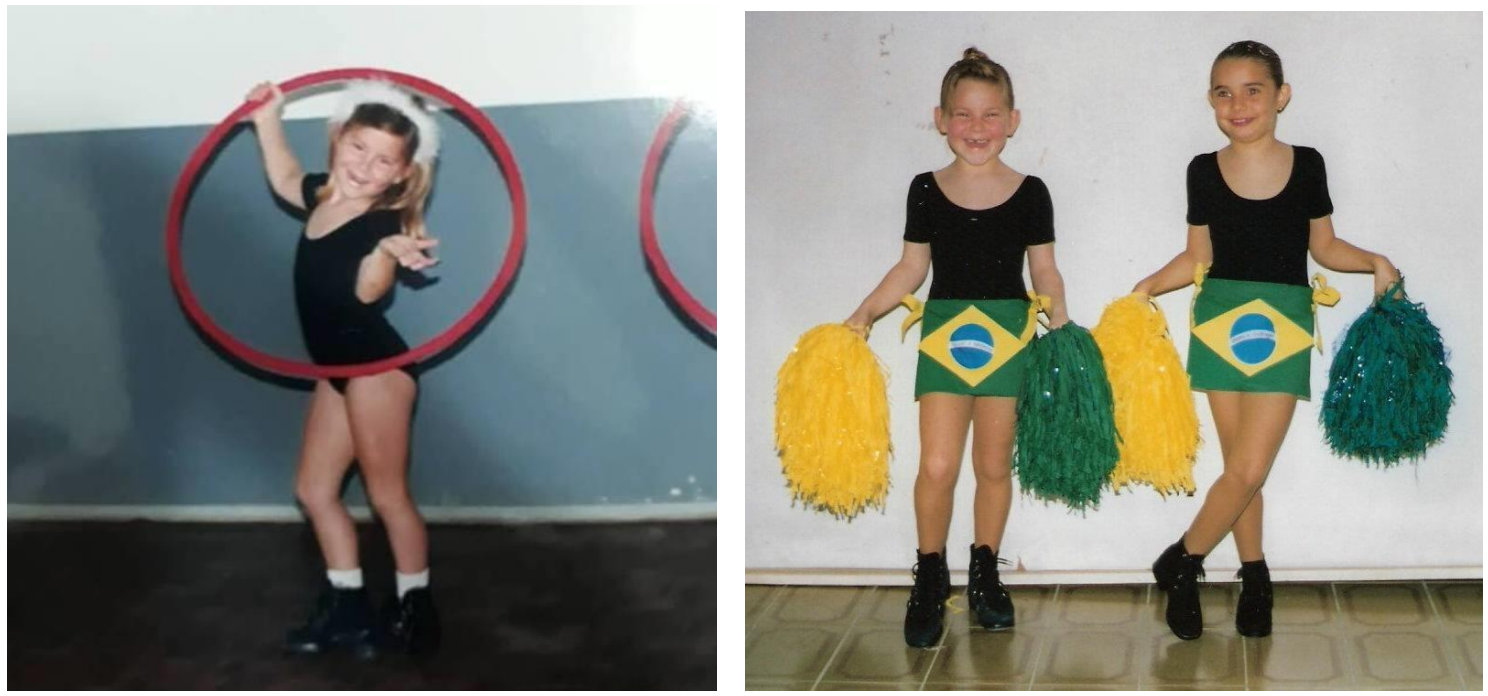

Figuras: 8 e 9: Elementos cênicos usados em algumas das coreografias Fonte: Arquivo pessoal

Apesar da carência de técnicas de algumas modalidades específicas, consideradas importantes para base na dança ${ }^{4}$, era visível uma preocupação estética e uma veia artística na assinatura de seus trabalhos, que não resumiam-se a um "amontoado de passos". Sua dança comunicava.
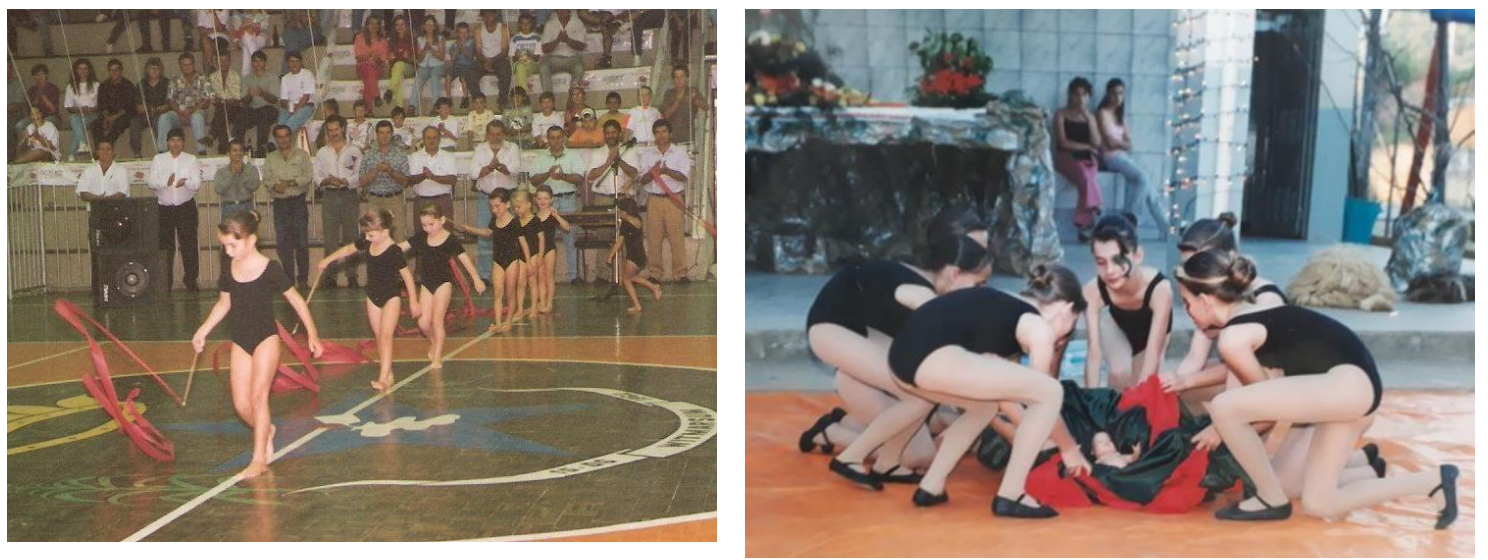

Figuras 10, e 11: Danças elaboradas para eventos natalinos.

Fonte; Arquivo pessoal

\footnotetext{
4 Será que existe mesmo "base para dança?". Ou este é um discurso falho que estamos acostumados a ouvir dos defensores do método tradicional de ensino, praticantes de ballet por exemplo? Até onde não saber fazer um grand jeté ou não ser tão en dehor atrapalha o desempenho, quando se dança outras modalidades que não o clássico? Até onde o saber estas técnicas contribuem? A dança africana, por exemplo, é voltada para baixo, contrapondo-se à altivez do ballet. O contemporâneo explora os movimentos naturais, as danças folclóricas trazem a alegria e festividade do povo, as danças urbanas abusam de movimentos de contração... Será que "a base do ballet" realmente seria importante para praticar essas danças
} 

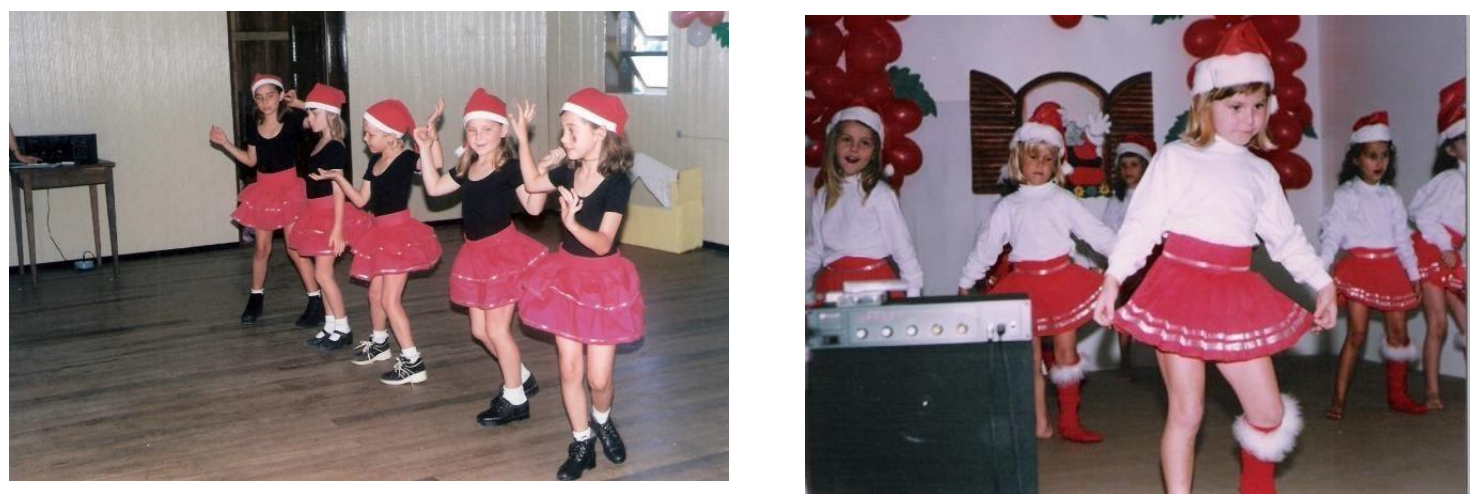

Figuras 12 e 13: Danças elaboradas para eventos natalinos. Fonte; Arquivo pessoal

Não tenho recordações de vê-la a frente da turma, afim de mostrar um modelo a ser copiado. Talvez por isso, nunca a tenha visto como uma bailarina, acho que nem mesmo como uma professora, e sim como uma mentora, alguém que nos apresentava possibilidades e nos levava a criar arte. Quando percebíamos, estávamos dançando. Isso ficou ainda mais claro no Ensino Fundamental, já na disciplina de ARTE. Ela nos fazia pensar, questionar e descobrir nossos próprios caminhos e talentos. Essa prática la de encontro a proposta de Barbosa (1979), ao dizer que "A Arte na educação tem como finalidade principal permitir que a criança expresse seus sentimentos e a idéia de que a Arte não é ensinada, mas expressada". (Barbosa, 1979, p.46, apud CHIARELLI, Lígia Karina Meneghetti e SIEBERT, Emanuele Cristina, 2009, p. 3016).

A partir dessas lembranças, é difícil definir minhas primeiras vivências na dança como pertencentes a determinada corrente pedagógica específica. Se considerarmos a presente preocupação estética com o produto final, poderíamos fazer alguma relação com a pedagogia tradicional, aplicada no Ballet por exemplo. No entanto, ao pensarmos na dança enquanto processo, acredito que sua prática está estreitamente ligada à Dança Criativa que, de acordo com Stinson (1995, p. 82) não é elitista ("Todos podem dançar!") nem tem foco no treinamento, mas é sobre educação. Encoraja a auto expressão e ensina a solução de problemas, não a passividade, e usa o movimento natural, ao invés de formas estilísticas idealizadas. Apesar de, nas aulas da professora Giovana, existir a reprodução de movimentos previamente estabelecidos, ela respeitava a organicidade e adequação desses movimentos 
em cada corpo. Na Pedagogia da Dança Criativa, o professor também é compreensivo e carinhoso, o que era uma característica inegável. O modelo para esse tipo de pedagogia é o da "mãe amorosa". Arce e Dácio (2007) propõe uma definição para "Dança Criativa" que se adequa perfeitamente a forma com que ela trabalhava:

O que a Dança Criativa pretende mostrar é que sua prática fornece os
subsídios necessários para o desenvolvimento espontâneo e criativo
da linguagem do movimento; tem o objetivo de desenvolver uma
ação pedagógica coerente, estimulando a criatividade,
baseando- se em análises de técnicas da dança adequada às séries,
com enfoque na educação psicomotora. [...] É um método de trabalho
que foge de determinadas regras estereotipadas e que valoriza o
processo criativo, estimulando o aluno à novas explorações e o
professor a renovar sempre.

O que difere a prática pedagógica de minha irmã da chamada "Dança Criativa", é o fato de que, na Dança Criativa, como consequência, pode ou não surgir um produto coreográfico. Já suas aulas, por mais que valorizassem o processo, objetivavam sempre um produto final.

Não consigo lembrar exatamente o porquê minha irmã acabou se afastando da prática da dança, acredito que outros interesses na arte, na vida acadêmica, profissional e pessoal tenham se sobressaído, mas tenho ciência de que suas sementes foram plantadas fortemente em mim, e continuam sendo regadas por ela até hoje.

\section{A criança dança}

"E a gente canta
E a gente dança
E a gente não se cansa
De ser criança
A gente brinca
Na nossa velha infância"
(Trecho da música "Velha infância" - Tribalistas)

Nos palcos ou não, a dança me era intrínseca desde pequena, e esteve presente em minha vida também de maneira informal. Posso dizer que as Artes Cênicas sempre me realizaram, e isso já estava presente nas próprias brincadeiras da infância. Como outras crianças, eu dava asas à minha 
imaginação e, mesmo sem saber, já mostrava aspirações futuras. Lembro que adorava brincar de circo, criando malabarismos coreografados num grande balanço do lado de casa. Compunha figurinos improvisados para as mais diversas performances $e$, de alguma forma, a ideia de estar à

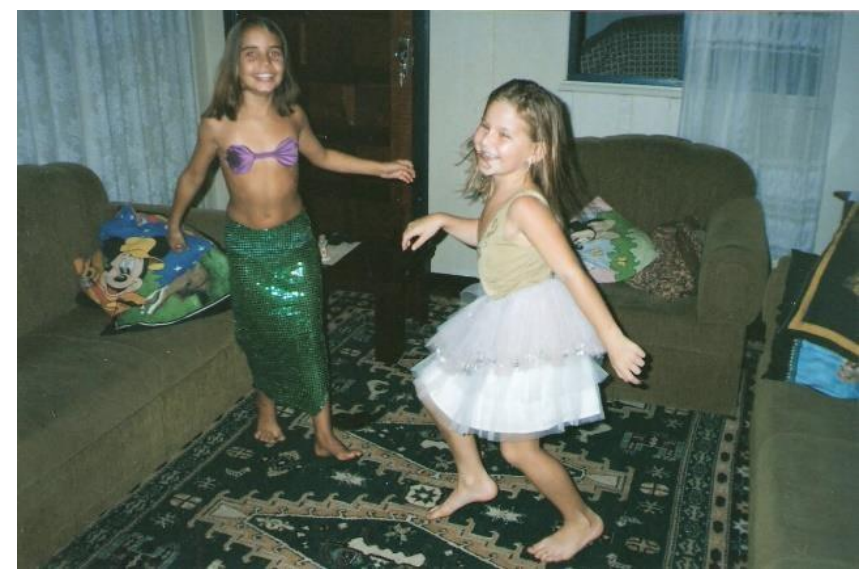

Figura 14: Momentos de brincadeira

Fonte: Arquivo pessoal frente de um público me

agradava bastante. Nestas brincadeiras eu explorava meu lado líder e criativo, e descobria o gosto pelas superproduções, mesmo que um tanto utópicas para minha realidade.

Não sei dizer se a dança me aproximava da brincadeira ou se as brincadeiras me aproximaram da dança, mas acredito que a Arte, de maneira geral, tem uma forte conexão com a infância. É nessa fase da vida que mais sonhamos e exercitamos nossa criatividade. Sem as amarras da vida adulta, a criança normalmente se deixa afetar e encantar pelas artes representativas e, se Ihe é proporcionado vivenciar arte para além do momento de brincar, facilmente ela a trará para sua vida adulta de alguma maneira, seja como apreciador ou como artista. Assim sendo, acredito que minha infância, e a Educação informal, dentro de um contexto familiar que sempre me aproximou da arte, seja também responsável pelas escolhas acadêmicas e profissionais que fiz, e as próprias brincadeiras também me propuseram qualidades de movimento e desenvolveram expressões corporais presentes em mim até hoje.

\section{As diferentes vivências na dança durante a adolescência}

Depois de minha irmã, ainda na infância e adolescência, tive outras três professoras de dança. Duas delas tinham alguma bagagem de conhecimento técnico, porém, curiosamente, guardo pouquíssimas lembranças e boas recordações dessas aulas. As professoras se mantinham mais distante das alunas, não havia muita troca de afeto, nem liberdade de movimento. Era mais 
uma relação de respeito, onde nossos gostos e opiniões não contavam muito e, consequentemente, as aulas não eram tão prazerosas.

A metodologia de ambas está claramente pautada na Pedagogia Tradicional do Ensino da Dança, que prima pela formação de "Corpos dóceis. ${ }^{\text {" }}$ O Professor explica, demonstra e os corrige exercícios, sendo autoridade máxima e a única fonte de conhecimento. Os alunos apenas aprendem a reproduzir o que recebem e não a criticar e criar arte, dança, movimentos... Sentimentos e emoções são reprimidos, a interação não existe ou é suprimida é há uma certa hierarquia e competição entre os alunos. Além do que, o corpo é visto como objeto a ser julgado, e valoriza-se que seja esbelto e comprido - um grande problema e, talvez, motivo das maiores frustrações na dança para mim. Tassiana Resende (2010, p. 12-13), em seu artigo "Outros olhares para o ensino do Ballet Clássico", fala sobre essa visão do corpo como objeto, especificamente no ballet, mas que podemos facilmente associar a outras modalidades de danças, quando empregada a Pedagogia Tradicional:

O ballet clássico possui uma ligação muito estreita com a imagem
do bailarino/aluno. Esse estilo de dança codificado, pré-
formatado, criou um padrão de corpo dito ideal, uma estética
única para quem o pratica. Os bailarinos/alunos
influenciados por este padrão estético, buscam
frequentemente, na esperança de poderem se aproximarem
ao máximo deste padrão, uma forma física muitas vezes irreal e
incompatível com a sua natureza de cada um. [...] A
impossibilidade de o corpo ser visto como sujeito, aquele corpo
que segundo Shapiro (1991) guarda memória da vida de uma
pessoa, que define a identidade racial de alguém, sua existência
com base nas diferenças de gênero, sua base histórica e cultural.
Na realidade, a própria materialidade da existência pode estar
relacionada com a pouca preocupação com a qualidade ou
com a consciência do processo educativo.

\footnotetext{
5 Michel Foucault (1926-1984) chama de "Corpos dóceis" os indivíduos disciplinados e fabricados à submissão, sujeição. O corpo é obediente, com movimentos detalhados, e sutil na forma e na disciplina adquirida.
} 
Quase não tenho memórias das aulas e apresentações com a professora "A". Fui sua aluna bailarina por pouquíssimo tempo. Lembro apenas que, apesar da postura de professora de Ballet, as coreografias trabalhadas conosco usavam

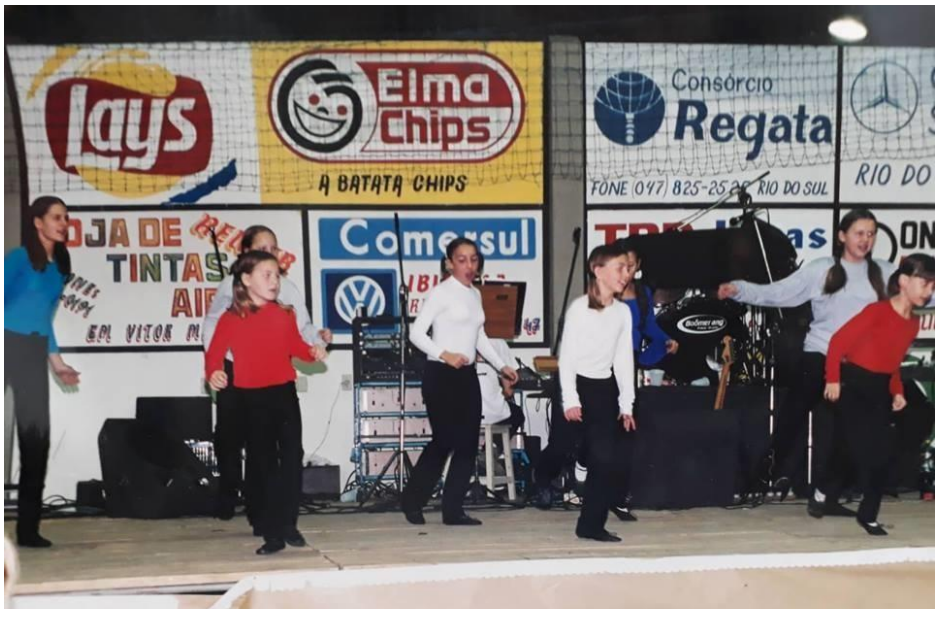

Figura 15: Apresentação coordenada pela prof “ “ $A$ ”, em Witmarsum.

Fonte: Arquivo pessoal

geralmente músicas conhecidas pelos jovens, pop e animadas, bem como os movimentos propostos. Acredito que sua formação em Educação Física tenha influenciado bastante nessas escolhas.

Não vejo qualquer semelhança do que fazíamos com ballet, jazz ou até eom as danças urbanas. Talvez pudéssemos chamar de "dança livre". Essa necessidade que percebo de nomearmos as danças é algo com o qual venho lidando desde que passei a estudar Dança formalmente. Confesso que me incomoda um pouco. Tenho a sensação de que, se não soubermos encaixar nossa dança em determinadas gavetas, ela deixa de ser dança ou, pelo menos, deixa de ser boa. Acredito que isso seja reflexo, principalmente, do que os festivais competitivos, baseados em modalidades, nos impõe, e me sinto um pouco na obrigação de encontrar "nomenclaturas para minha dança". Mas, ao mesmo tempo, quando penso a dança enquanto arte ${ }^{6} \mathrm{e}$ sendo a arte completamente subjetiva e em constante transformação, me pergunto: Por que teríamos a obrigação de adequar nossa dança a formatos préestabelecidos, correndo o risco de perdermos nossa identidade enquanto artistas, sendo que ela - a dança - nos é tão particular, reflexo muitas vezes de nossas vivências corporais e afetivas?

\footnotetext{
6 Jaqueline Smith Autard, mundialmente reconhecida como uma líder na educação da dança, defende a ideia da dança enquanto Arte a partir da execução, criação e observação. Flavia Pilla do Valle (2012, p. 15) cita Autard em sua tese de doutorado e diz que para ela “(...) compor uma dança é compor um trabalho artístico e, portanto, há que se ter uma preocupação com o todo. (...) a educação em dança como arte envolve uma educação estética. O foco do trabalho com os alunos deve ser na dança como arte, através da composição, performance (no sentido de fazer e praticar dança) e apreciação de dança." 
Somos todos corpos atravessados pelas linhas contínuas e ilimitadas resultantes dos choques causados pelos encontros. Linhas afetivas que nos seus movimentos de repulsa, atração e (des)ligamentos tecem experiências corporais. Fazem e desfazem corpos. As linhas que nos traçam são "feiticeiras", como a dança e a infância, e por isso nos encantam. Arrastam nossos corpos para mais além. Interrogam- nos sobre o que somos, fazemos e podemos. São linhas de fuga que desenham e desmancham formas e movimentos corporais. Linhas dançarinas que ziguezagueiam e traçam devires para o corpus socioindividual. (ROSA, 2016, p. 163)

Levando em consideração esses rótulos estabelecidos, o pouco contato que tive com o jazz foi, logo depois, com a professora "B". O estilo ficava evidente nas sapatilhas "botinha" que usávamos, na escolha das músicas, figurinos e movimentos realizados que não tinham a rigidez do ballet mas também não eram orgânicos/naturais. Para mim, especialmente, não eram movimentos confortáveis - parecia que meu corpo, cheio de curvas e "molejos" não se adequava naquilo, e eu não me sentia comunicando nada com aquela dança, apenas executava o movimento. - É fato que também fiz aula com ela por pouco tempo, mas não posso dizer que de fato aprendi, internalizei e reconheço qualquer técnica do jazz.

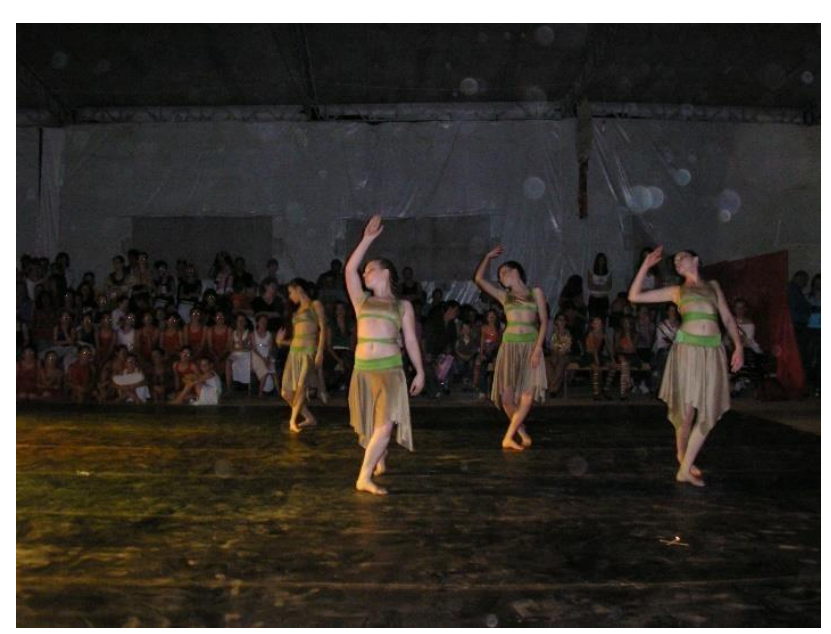

Figuras 16, 17 e 18: Apresentações das coreografias da professora " $B$ "
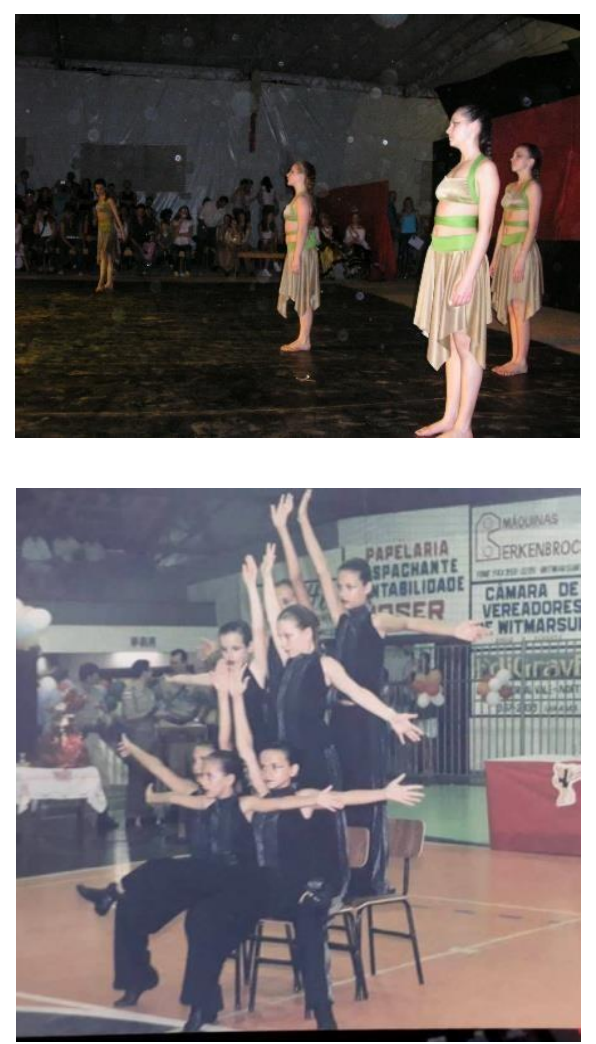
Já a terceira e última professora de dança que tive na juventude tinha uma prática bem diferente. Ela não tinha qualquer formação técnica, apenas gostava de dançar e resolveu se dedicar a isso. Formamos um grupo de crianças e adolescentes liderados por ela que representava a cidade em diversos eventos. Muitas meninas e alguns meninos. Essa sempre foi uma característica marcante nos grupos de dança, principalmente infantis e de cidades pequenas. Hoje, quase 20 anos depois, pelos próprios grupos que lidero, vejo que a adesão dos meninos à dança é algo mais comum, mas que ainda há muitas barreiras, resistência e preconceitos a serem quebrados para que possamos nivelar estas estatísticas.

As coreografias que levavam o nome da professora " $\mathrm{C}$ ", tinham grande participação das alunas, principalmente as "mais experientes" (como acreditávamos ser). Contribuíamos para a criação, bem como para a escolha de músicas e figurinos. Dessa maneira, tudo acabava ficando bem com "a nossa cara". As aulas eram divertidas. Lembro que eu esperava ansiosa pelo "dia da aula de dança". Acredito que a lembrança dessa sensação se deve, em grande parte, por nos sentirmos responsáveis pelos resultados, também por dançarmos o que gostávamos de ouvir, pelos movimentos mais soltos e livres de exigências corporais, e por termos um grupo misto, com relacionamentos afetivos, entre os próprios alunos e com a professora, que tínhamos como amiga.

Apesar das lembranças prazerosas das aulas, nos sentíamos um tanto frustrados quando comparávamos nossos resultados com os de outros grupos, justamente pela falta de qualidade técnica. Isso me leva a alguns questionamentos: O que, principalmente, deve ser trabalhado na dança durante a infância? O quanto a técnica deve ser valorizada? Como lidar com esse sentimento de inferioridade das crianças diante de seus resultados, que muitas vezes se sobrepõe a riqueza e alegrias do processo?

Independentemente do quanto as aulas com a professora Sabrina me agregaram em relação a conhecimentos técnicos específicos na dança, sei que essas vivências acabaram por alimentar em mim o amor por esta Arte que, lá atrás já havia sido plantado, e são dessa época minhas maiores lembranças. 

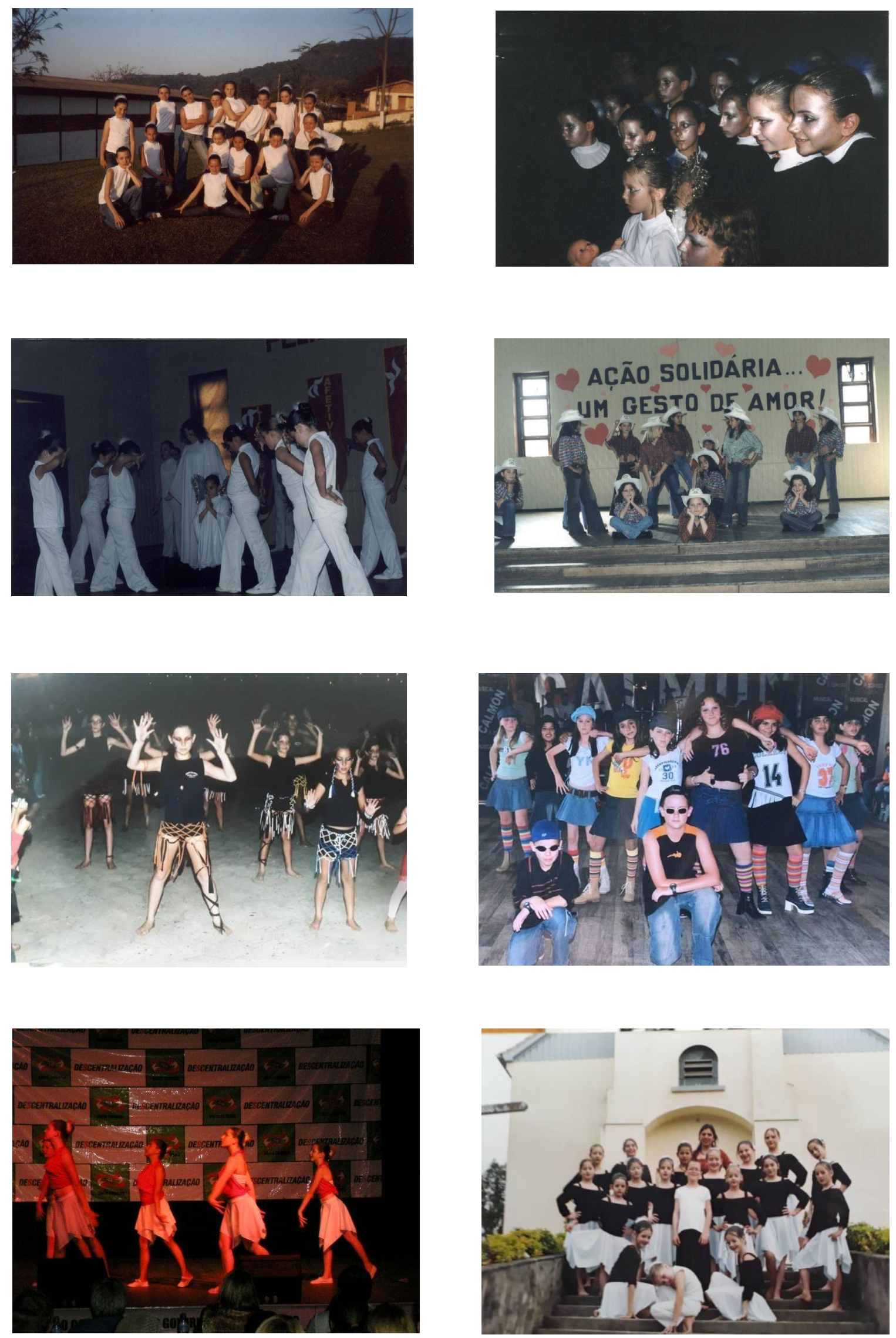

Figuras: 19, 20, 21, 22, 23, 24, 25, e 26: Apresentações do grupo "Estrela Azul” coordenado pela prof " " $C$ ".

Fonte: Arquivo pessoal 
Refletindo sobre sua didática, posso compará-la à da Pedagogia Feminista para a dança da Criança, apesentada por Susan Stinson (1995), especialmente por conta da valorização do relacionamento e pela descentralização da autoridade (o professor não é a única fonte de conhecimento e o poder passa a ser compartilhado), dessa forma, há menos hierarquia e mais trabalho em grupo.

\title{
3. A dança no contexto escolar
}

\begin{abstract}
Toda dança promove transformação, logo, toda dança é educação. E é por essa razão que termos como 'dança educativa', 'dança expressiva', 'dança criativa', e tantas outras nomenclaturas para nomear a dança trabalhada na escola devem ser evitadas. A dança em si já é educativa, expressiva e criativa, dispensando adjetivos. Se não é constituída desses três fatores, então, simplesmente não é dança. (STRAZZACAPPA, 2001, p.44)
\end{abstract}

No ensino formal, apesar das aula de Artes - lecionadas pela minha irmã - por vezes colocarem a dança em pauta, não havia nenhuma aproximação em outros componentes curriculares, a não ser que se partisse dos próprios alunos em suas apresentações de trabalhos por exemplo (eu, de uma forma ou de outra sempre acabava usando da dança em diferentes oportunidades).

A disciplina de Educação Física sempre foi voltada para o lado esportivo e esteve distante da dança. A problemática da dança compor duas áreas de conhecimento é apresentada por Morandi (2006, p. 75, apud SOUZA, 2012):

\footnotetext{
O fato de a dança se apresentar como conteúdo em duas áreas de conhecimento poderia contribuir para sua efetiva ocorrência nas escolas, mas por outro lado, pode destituir a responsabilidade de uma área já que a outra desenvolve esse conteúdo.
}

A única vez em que a Dança esteve presente nas aulas de Educação Física, foi quando um professor resolveu trabalhar, em uma ou duas aulas, a dança de salão. Apesar de formado em E.F., faltava-Ihe didática para o ensino da Dança, e as aulas não foram muito produtivas em relação ao conhecimento específico adquirido. Ele basicamente pediu que nos permitíssemos formar duplas de meninos com meninas, e procurou orientar um "dois pra lá, e dois pra cá”, que acompanhasse o ritmo da música. Mesmo assim, para mim 
especialmente, as aulas acabaram sendo prazerosas (acredito que por serem de meu interesse). Lembro de esperar que aquela "prática de dança" se repetisse nos anos seguintes. Não aconteceu.

Eu não tinha ciência, mas hoje vejo o quanto teria sido enriquecedor se a dança dentro do ambiente escolar durante meu Ensino Fundamental e Médio, tivesse sido mais explorada, não apenas como instrumento pedagógico, mas como conteúdo em si.

A Dança na escola pode servir de incentivo para que a criança se torne artista, ao the possibilitar o contato com esse universo mágico. Mas a dança na escola só serve de estopim. A formação do profissional se dá fora desse ambiente. A educação básica torna-se responsável, acima de tudo, pela formação de indivíduos sensíveis. Assim, a dança na escola não forma o artista, mas pode formar um púbico de arte (STRAZZACAPPA, 2001, p.57)

\section{A dança fora dos palcos}

Por Witmarsum ser uma cidade interiorana, a dança de salão sempre foi algo comum nos bailes e festas locais (talvez por isso as escolha do professor de E.F.). Dessa forma, no que se refere à Dança de Salão, acredito que eu acabei aprendendo a dançar... Dançando! Literalmente. Ninguém parou e me ensinou uma técnica específica da dança gaúcha por exemplo (apesar de, em certos

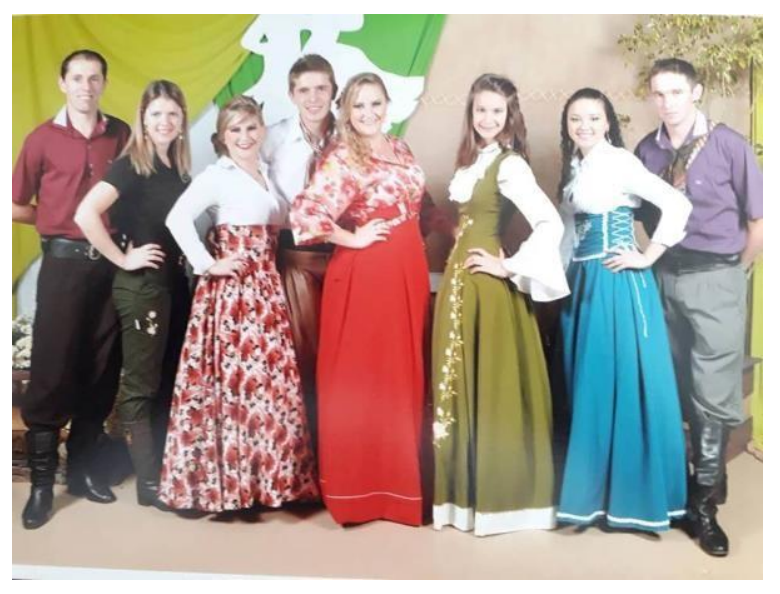

Figura 27: Baile de Formatura de Curso de Dança Gauchesca (Witmarsum) Fonte: Arquivo Pessoal momentos, serem ofertados $\operatorname{cursos}^{7}$ na cidade, dos quais nunca participei). Mas no contexto festivo, a dança simplesmente acontecia.

É interessante perceber que essa presença da dança no meu dia-a-dia, sem qualquer formalismo educacional, também faz parte de minha formação enquanto ser dançante pensante, e pensar o quanto isso influenciou na minha

\footnotetext{
${ }^{7}$ Cursos de curta duração, ministrados por professores de outras cidades, que vinham de tempos em tempos formar turmas iniciantes, afim de ensinar os passos básicos dos principais ritmos de Dança Gaúcha de salão.
} 
forma de dançar hoje. As danças populares, em sua essência, permitem-nos descobrirmos, de maneira natural, as possibilidades de movimento e os prazeres da prática da dança. O foco está na sensação do "bailarino", e não na percepção do púbico. Isso transforma totalmente os corpos que dançam.

\title{
5. O reencontro com a dança na vida adulta e a descoberta de uma realização profissional
}

\author{
"No canto do cisco \\ No canto do olho \\ A menina dança \\ E dentro da menina \\ A menina dança \\ E se você fechar o olho \\ A menina ainda dança \\ Dentro da menina \\ Ainda dança" \\ (Trecho da música "A menina dança" dos Novos Baianos)
}

Ao sair da escola, a dança acabou se ausentando da minha vida por um tempo. Na faculdade de Artes Visuais não tive nada que a envolvesse. Depois de adulta, qualquer contato com dança se tornou algo esporádico, em oficinas, festas, academias, etc.

Enquanto professora de ARTE, sempre procurei contemplar diversas linguagens, e a dança se faz presente em minhas aulas. Essa prática docente acabou me levando a trabalhar com a dança escolar ${ }^{8}$ e, por fim, tornei-me - já no Ensino Superior - uma estudante de dança. A partir de então passei a percebê-la de outras maneiras, recebendo e construindo, e procurando absorver em pouco tempo, muito conhecimento, vivenciando a dança intensamente, dentro e fora da universidade.

\begin{abstract}
A dança no contexto universitário de certo modo expande como se concebe o ensino da dança, pois no diálogo entre diferentes áreas de conhecimentos e nas vivências em diferentes estilos de dança e nos modos de ensiná-las, concebê-las e recriá-las, os graduandos tem a possibilidade de ressignificar suas práticas anteriores. (SOUZA, 2012)
\end{abstract}

Após uma análise de toda minha trajetória e memórias no ensino da dança, bem como as correntes pedagógicas presentes nesse processo de formação, faço

\footnotetext{
${ }^{8}$ Participo como professora de Dança e Teatro de um projeto de incentivo à Cultura, desenvolvido na escola pública estadual em que também trabalho com a disciplina de ARTE.
} 
ainda, uma rápida leitura desse mais recente contato que tenho com dança (de maneira formal e já no Ensino Superior). Diante das tendências estudadas, posso dizer que o Curso de Graduação em Dança da FURB assume uma postura crítica de ensino, ajudando os alunos a questionar e propor alternativas, com abordagem estreitamente alinhada ao trabalho de Paulo Freire, autor da Pedagogia do Oprimido ${ }^{9}$. De acordo com Stinson (1995)

A pedagogia crítica, assim como é descrita por seus defensores, demanda uma capacidade de pensamento abstrato por parte de seus participantes. Isso parece implicar uma possiblidade de aplica-la para o ensino da dança para adultos e adolescentes, mas não para crianças.

\section{A memória enquanto dança do pensamento: considerações finais}

Ao desenvolver e concluir este trabalho, após recordar e pensar sobre as correntes metodológicas presentes em minha trajetória na Dança, faço a mim mesma algumas perguntas, que talvez sejam pertinentes para o momento enquanto graduanda numa licenciatura em Dança, e tento responde-las: Primeiramente, 0 quanto as diferentes abordagens pedagógicas que tive influenciaram na professora que sou hoje? E ao rever minha história, na posição de estudante e pesquisadora, eu diria que... Muito! Tudo o que vivenciei, tendo sido positivo ou não, me atravessa, e provavelmente, as vivências informais e não formais até aqui, são as maiores responsáveis pela professora que me tornei. Penso agora que, a Graduação em Dança, apesar de me trazer muito conhecimento prático e teórico sobre esse universo tão vasto, tem como papel principal me fazer perceber essas vivências e organizar meus pensamentos e conhecimentos obtidos até hoje, afim de utilizá-los da melhor forma enquanto profissional da educação.

As palavras do relato pessoal de Tassiana Resende também me cabem muito bem quando diz:

Percebi que a variedade de professores e coreógrafos com os quais trabalhei me fez enxergar, aprender e a ver a dança com um outro olhar. A variedade de estilos vivenciados e experimentados me fizeram enxergar a importância individual de cada um deles, o desafio que é transitar entre estes vários estilos de dança e o mais importante, a contribuição que estes trazem um para o outro.

A alta exigência da técnica clássica contribui para que os bailarinos se tornem meros executantes de movimentos, tirando com isso, o prazer pela dança. Segundo Marques (2007), ao contrário do que nos

\footnotetext{
9 Livro propõe uma pedagogia com uma nova forma de relacionamento entre professor, estudante, e sociedade.
} 
dita o senso comum, as aulas de dança podem ser verdadeiras prisões dos sentidos, das idéias, dos prazeres, da percepção e das relações que podemos traçar com o mundo.

Por fim, me pergunto ainda o quanto o não ter feito aulas de Dança Clássica ou não ter me aprofundado em outras técnicas específicas dificultou/facilitou/interferiu na minha trajetória na Educação Formal em Dança? Essa é uma questão que me fez refletir. Até pouco tempo, acreditava que este era um grande problema, e dificultaria bastante minha permanência num curso superior de Dança. No entanto, o que tenho estudado, ouvido e praticado até aqui, me faz ter a forte sensação de que o "não ter um corpo moldado" por estilos rígidos e técnicas fechadas, me faz estar mais aberta a tantas possibilidades presentes na Dança, o que é algo essencial visto que busco uma formação enquanto professora, não enquanto bailarina. Há em mim mais a se acrescentar do que a se descontruir.

"Não basta saber dançar, mas compreender por que se dança: compreender que a Dança pode constituir-se linguagem, possuir diferentes idiomas e, na construção de suas sintaxes, possibilitar o desenvolvimento dos seus conteúdos nos processos de formação."

(MORTARI, 2013, p. 9)

\section{REFERÊNCIAS}

ARCE, Carmem e DÁCIO, Gabriela Mavignier. A dança criativa e o potencial criativo: Dançando, criando e desenvolvendo. Revista Eletrônica Aboré. Publicação da Escola Superior de Artes e Turismo. 3ª Ed. 2007.

CHIARELLI, Lígia Karina Meneghetti e SIEBERT, Emanuele Cristina. Trajetória do Ensino Pedagógico no Caminho da Arte. III Encontro Sul Brasileiro de Psicopedagogia. 2009. Disponível em: <http://educere.bruc.com.br/arquivo/pdf2009/2490_1365.pdf>. Acesso em: 09 de setembro de 2018.

MORTARI, Katia Simone Martins. A Compreensão do Corpo na Dança: um olhar para a contemporaneidade. Universidade Técnica de Lisboa. Faculdade de Motricidade Humana. 2013.

PILLA DO VALLE, Flavia. Contraconduta da criação: Um estudo com alunos da Graduação em Dança. Universidade Federal do Rio Grande do Sul. Faculdade de Educação. Programa de Pós-graduação em Educação. Porto Alegre. 2012. 
RESENDE, Taciana Inês Stacciarini. Outros olhares para o ensino do Ballet Clássico. Pontifícia Universidade Católica de Goiás. Centro de Estudos Avançados e Formação Integrada - Especialização em Pedagogias da Dança. Goiás. 2010.

STRAZZACAPPA, Márcia. Dançando na chuva... E no chão de cimento. In FERREIRA, Sueli (org.). O ensino das artes: Construindo caminhos. $1^{\text {a }} \mathrm{Ed}$. Campinas, SP: Papirus, 2001.

SOUZA, Andréa Bittencourt de. Um Currículo da dança ou para dança? IX Seminário de Pesquisa em Educação da Região Sul. 2012.

STINSON, Susan W. Uma pedagogia feminista para a Dança da Criança.

Pro-posições. Vol. 6. 1995. 